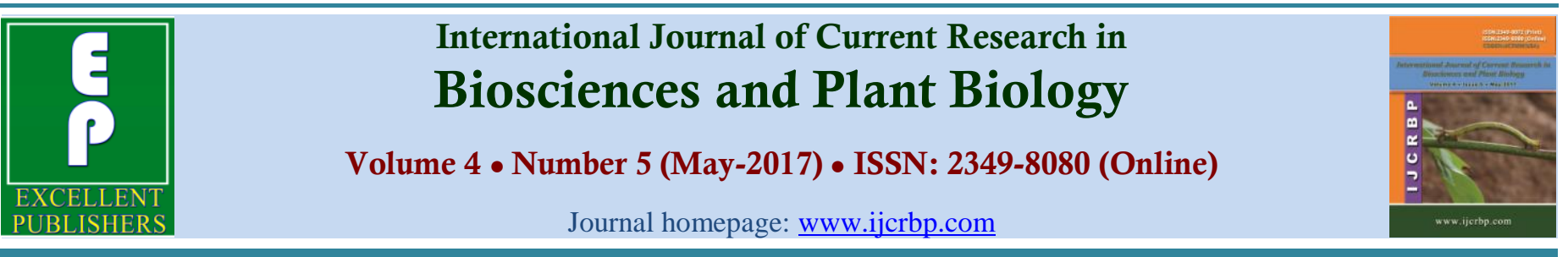

\title{
Ethnobotanical Investigation of Lippia multiflora Moldenke, a Local Aromatic Leafy Vegetable under Domestication in Benin
}

\author{
H. W. Djengue ${ }^{1}$, A. Dansi ${ }^{1,2}$, A. Adjatin ${ }^{1,2}$, I. Dossou-Aminon ${ }^{1,2^{*}}$, M. Dansi ${ }^{1,2}$ and A. Sanni ${ }^{3}$ \\ ${ }^{1}$ Laboratory of Biotechnology, Genetic Resources and Plant and Animal Breeding (BIORAVE), Faculty of Sciences and \\ Technology of Dassa, University of Abomey-Calavi, BP 143, Dassa, Benin \\ ${ }^{2}$ Institut de Recherche, de Formation et de Développement sur les Plantes Cultivées, les Animaux d'Elevage et les plantes \\ Médicinales (IRDCAM), 071BP28, Cotonou, Benin \\ ${ }^{3}$ Laboratory of Biochemistry and Molecular Biology, Faculty of Sciences and Technology (FAST), University of Abomey-Calavi \\ (UAC), P.O. Box 526 Cotonou, Benin
}

*Corresponding author.

\begin{tabular}{|c|c|}
\hline Abstract & Article Info \\
\hline \multirow{3}{*}{$\begin{array}{l}\text { Lippia multiflora is one of the widely known and used aromatic and medicinal leafy } \\
\text { vegetable in central Benin. Because very little research is done on this almost wild } \\
\text { species, it is classified among the so called neglected and underutilised species of Benin. } \\
\text { To fill the gap of scientific knowledge on this species, an ethnobotanical survey has been } \\
\text { conducted in } 38 \text { villages randomly selected in central Benin using participatory research } \\
\text { appraisal. The study revealed that Lippia multiflora is located in central Benin. Its } \\
\text { vernacular names vary across ethnic groups. It is called aklala, kanwun, tchagara, } \\
\text { kuinwounkuin and yinyan with the Mahi, Idasha, Ifè, Tchabè and Fon ethnic groups } \\
\text { respectively. In Benin the domestication of Lippia multiflora has started and the species } \\
\text { was found at level } 1 \text { of the plant domestication process in } 55.55 \% \text { of villages surveyed. } \\
\text { The leaves ( } 60 \% \text { of respondent), flowers (25\% of respondents), roots (10\% of } \\
\text { respondents) and stems (5\% of respondents) of the plant are used for various medicinal } \\
\text { purposes. Lippia multiflora is mostly ( } 76.92 \% \text { of interviewees) consumed as leafy } \\
\text { vegetable. Its consumption frequency and method vary throughout ethnic areas. Lippia } \\
\text { multiflora was found to have a lot of medicinal value and is therefore a good nutraceutical. }\end{array}$} & $\begin{array}{l}\text { Accepted: } 15 \text { March } 2017 \\
\text { Available Online: } 06 \text { May } 2017\end{array}$ \\
\hline & Keywords \\
\hline & $\begin{array}{l}\text { Aromatic plants } \\
\text { Ethnobotanical study } \\
\text { Leafy vegetable } \\
\text { Lippia multiflora } \\
\text { Nutraceutical }\end{array}$ \\
\hline
\end{tabular}

\section{Introduction}

From the approximately 300,000 plant species of the planet, more than 200,000 are in the tropical countries of Africa and have medicinal virtues (Mangambu et al., 2014). In Benin, Akoègninou et al. (2006) reported the existence of 2,807 plant species among with the local leafy vegetables such as Amarant and Lippia multiflora.
Leafy vegetables are plants of which the leaves (including buds and flowers) are used and consumed by the local populations (Dansi et al., 2008).

Lippia multiflora is an aromatic plant, a shrub of the Verbenaceae family (Mindiédiba et al., 2013) of which inflorescences, leaves and roots are used for food or medicine in Benin where it is traditionally known as 
endowed with a lot of medicinal virtues (Adjanohoun and de Souza, 2002; Akoègninou et al., 2006). Across Africa, the plant is traditionally used to treat bronchial affections, malaria, conjunctivitis, gastric unrests, enteritis, cough and the rum (Pascual et al., 2001). It also possesses some anti-hypertensive, relaxing, diuretic and antibiotic properties (Kanco et al., 2004; Ekissi et al., 2014). In Cote d'Ivoire, the plant is used to treat icterus and diarrhea (Bouquet and Debray, 1974; Oussou et al., 2008).

In Benin, the vegetable L. multiflora is also reported to have medicinal value (Dansi et al., 2008; Dansi et al., 2012). In the medicinal plants markets Lippia multiflora is among the more recommended and sold plants for the treatment of diabetes (Fah et al., 2013). Despite its importance, the species is still less researched and the aspects studied are only related to the characteristics of its essential oil (Avlessi et al., 2005). Very little is known on its diversity, geographical distribution, folk nomenclature, domestication and uses. The present study was designed to fill these gaps of knowledge.

\section{Materials and methods}

\section{Study area and sites selection}

Thirty-eight (38) villages (17 in south, 09 in central region, and 12 in the north; Table 1) were selected from different agro-ecological and ethnic zones for the survey. Villages in which the species was found during the national leafy vegetables inventory mission were also considered for the survey (Dansi et al., 2008).

Table 1. Villages, administrative zones and ethnic groups surveyed.

\begin{tabular}{|c|c|c|c|c|}
\hline $\mathbf{N}^{\circ}$ & Villages & Districts & Regions & Ethnic groups \\
\hline 1 & Adjantè & Bantè & Center & Tcha \\
\hline 2 & Atokolibé & Bantè & Center & Ifè \\
\hline 3 & Aïzè & Ouinhi & Center & Fon \\
\hline 4 & Awokpa & Zè & South & Aizo \\
\hline 5 & Bétérou & Tchaourou & North & Bariba \\
\hline 6 & Cotiakou & Tanguiéta & North & Wama \\
\hline 7 & Coussinlélé & Covè & Center & Fon \\
\hline 8 & Dévé & Dogbo & South & Adja \\
\hline 9 & Dogbo-Kounacho & Adja-Ouèrè & South & Holli \\
\hline 10 & Dogo & Kétou & South & Mahi \\
\hline 11 & Domè & Zogbodomè & South & Fon \\
\hline 12 & Dovi-Zounou & Zangnanado & Center & Mahi \\
\hline 13 & Fô-tancé & Kouandé & North & Bariba \\
\hline 14 & Gativé & Comè & South & Watchi \\
\hline 15 & Guézo-houé & Kpomassè & South & Sahouè \\
\hline 16 & Gobè & Savè & Center & Idaatcha \\
\hline 17 & Gouti & Adjohoun & South & Wémè \\
\hline 18 & Hètin-sota & Dangbo & South & Wémè \\
\hline 19 & Hokpamè & Athiémè & South & Adja \\
\hline 20 & Houèda & Adjohoun & South & Wémè \\
\hline 21 & Hounga-houégbé & Houéyogbé & South & Sahouè \\
\hline 22 & Kpassabéga & Copargo & North & Yom \\
\hline 23 & Kodowari & Bassila & North & Annii \\
\hline 24 & Lagbavé & Aplahoué & South & Adja \\
\hline 25 & Madécali & Malanville & North & Dendi \\
\hline 26 & Madjavi & Djidja & Center & Fon \\
\hline 27 & Mitro & Dangbo & South & Wémè \\
\hline 28 & Monkpa & Savalou & Center & Mahi \\
\hline 29 & Piami & Ségbana & North & Boo \\
\hline 30 & Sam & Kandi & North & Bariba \\
\hline 31 & Sanrin-kpinlé & Sakété & South & Wémé \\
\hline 32 & Sékéré & Sinendé & North & Bariba \\
\hline 33 & Sèmèrè & Ouaké & North & Foodo \\
\hline 34 & Sérékali & Nikki & North & Bariba \\
\hline 35 & Sowé & Glazoué & Center & Idaatcha \\
\hline 36 & Tandji & Lalo & South & Adja \\
\hline 37 & Toffo-centre & Toffo & South & Aïzo \\
\hline 38 & Toubougnini & Matéri & North & Berba \\
\hline
\end{tabular}




\section{Data collection and analysis}

The data were collected using participatory research appraisal based on questionnaire, group and individual interviews, direct observation in the fields, etc. following Adjatin et al. (2012) and Sanoussi et al. (2015). In each village, the interviews were facilitated by locally recruited interpreters as well as the chief of village. To facilitate the identification of the species a whole living plant of Lippia multiflora kept in pot is presented to the communities visited. In each village, some specific information (name of district, village and ethnic group) were first collected after detailed presentation of the research objectives to the farmers. During the discussion, the key information collected on the species were: vernacular name and its significance, status (wild, cultivated), season of availability, consumption period, part of the plant used for consumption, consumption method, degree of consumption, post-harvest conservation, perception on nutritional value, medicinal value and uses and cultural importance, culturally practices in the zones where it is cultivated and domestication level. For cultural practices, specific data collected were related to seeds conservation, seed germination (treatment and management of nurseries), density of seedling, use of pesticides and manures (type, dose and frequency), harvest (number and duration) and the cultural system (monoculture, mixed culture). The level of domestication of the species was determined in the different villages following Vodouhè and Dansi (2012).

Recorded data were analyzed through descriptive statistical (frequency, percentage, Mean, variance) and the results are presented in the form of tables and figures.

\section{Results and discussion}

\section{Geographical distribution of species}

The geographical distribution map of Lippia multiflora in Benin (Fig. 1) revealed that the species was found only in the villages of Bantè, Savalou, Glazoué, Savè, Djidja, Zogbodomey and Kétou districts, all located in central Benin corresponding to humid agroecological zone characterized by a rainfall oscillating between 900 to $1300 \mathrm{~mm}$ (Adomou, 2005). This zone is occupied by the ethnic groups Idasha, Fè, Fon and Tchabè (Adomou, 2005). Our results are similar to those of Akoègninou et al. (2006). Few people know the medicinal importance of the plant. When the information will circulated, the geographical distribution will significantly change as the plant is vegetative propagated and everybody will be looking at it for cultivation in home garden.

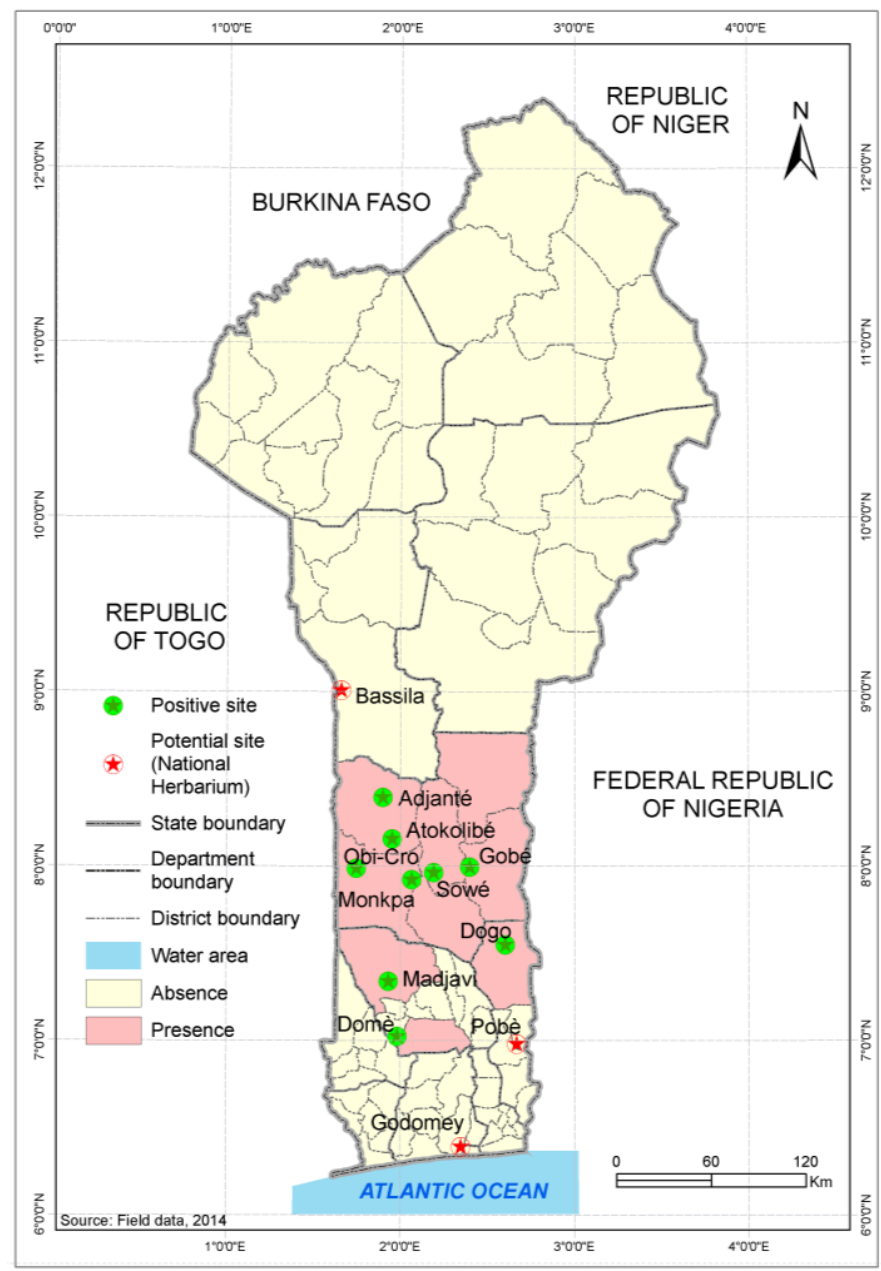

Fig. 1: Map of Benin showing the geographical distribution of Lippia multiflora.

\section{Folk nomenclature and level of domestication}

In the study area, five different vernacular names of Lippia multiflora were recorded. They vary from across ethnic groups. Hence, Lippia multiflora is called Aklala in Mahi, Kanwun in Idasha, Tchagara in Ifè, Kuinwounkuin in Tchabè and Yinyan in Fon. The real meaning of the names is still unknown by the populations as they have been simply inherited from their grandparents In folk nomenclature, variations of names through ethnic areas is very common and was reported on leafy vegetables (Adjatin et al., 2012; Sanoussi et al., 2015), sorghum (Dossou-Aminon et al., 2014), cassava (Agré et al., 2015) and even Lippia multiflora in Côte d'Ivoire (Ekissi et al., 2013). 
According to Pourkheirandish and Komatsuda (2007), plant domestication is defined as the evolutionary process whereby a population of plants becomes accustomed to human provision and control. It is generally considered to be the end-point of a continuum that starts with exploitation of wild plants, continues through cultivation of plants selected from the wild but not yet genetically different from wild plants and ends with the adaptation to the agro ecology through conscious or unconscious human morphological selection, and hence genetic differences distinguishing the domesticated species from its wild progenitor (Hammer, 1984; Harlan, 1992; Parker et al., 2010; Sakuma et al., 2011; Dansi et al., 2012). Therefore, it is essential to distinguish between true domestication and its initial phase called "bringing into cultivation".

Following Vodouhè et al. (2011), bringing into cultivation of leafy vegetable can be seen as a long process of seven steps leading to the development of the best cultural practices or technological packages necessary to master mass production in order to move from a proto-culture (wild species maintained in the fields for use when found during land preparation) to traditional home garden cultivation and later on to production in market gardens for food and economic purposes. These steps as defined by Vodouhè et al. (2011) and Dansi et al. (2012) are as follow:

- Step 0: Species entirely wild and collected only when needed;

- Step 1: Wild species maintained in the fields when found during land preparation;

- Step 2: Farmers start paying more attention to the preserved plants for their survival and their normal growth. A sort of ownership on the plants starts;

- Step 3: The reproductive biology of the species is understood and multiplication and cultivation of the species in the home gardens or in selected parts of cultivated fields are undertaken;

- Step 4: The species is produced (in sole cropping) and harvested using traditional practices;

- Step 5: To improve the quality of the product, farmers adopt specific criteria to select plants that better satisfied peoples' needs

- Step 6: Development of appropriate pests and disease protection and food processing methods.
As it is the case with Crassocephalum rubens (Adjatin et al., 2012), Bidens pilosa and Launaea taraxacifolia (Sanoussi et al., 2015), the domestication of Lippia multiflora in the sense of bringing into cultivation has started and its level vary from one village to another. Following the scale defined by Vodouhè et al. (2011), the species is at level 0 at Dome, level 1 at Adjante, Atokolibe, Gobe, Sowé and Dogo, level 2 at Obicro and Monkpa, level 4 at Madjavi. The other domestication level were not found in the villages visited (Fig. 2).

Reasons put forward by the interviewees to justify the domestication of Lippia multiflora are of five types: Regular consumption as vegetable (47.6\% of responses), scarcity of the species in the fields around the villages (20.7\% of responses), contribution to household income through commercialization (17.25\% of responses), high perceived medicinal value (12.52\% of responses) and difficulty of the harvesting in the bush $(1.93 \%$ of responses).

In reality, these five factors listed above portray three key aspects which are food, health and household income, the first two being the most important. These results which are in agreement with those reported by Hildebrand (2003) in southwest Ethiopia and Casas et al. (2007) in Mesoamerica are not surprising since plant domestication always seek to bring out the maximum human benefit within a species. They also support the statement of Vodouhè et al. (2011), Adjatin et al. (2012) according to which domestication of a plant starts, when its usefulness is proved, its demand is confirmed and regular, its availability around dwellings is seriously decreasing and when getting the desired quantity on time for use becomes problematic.

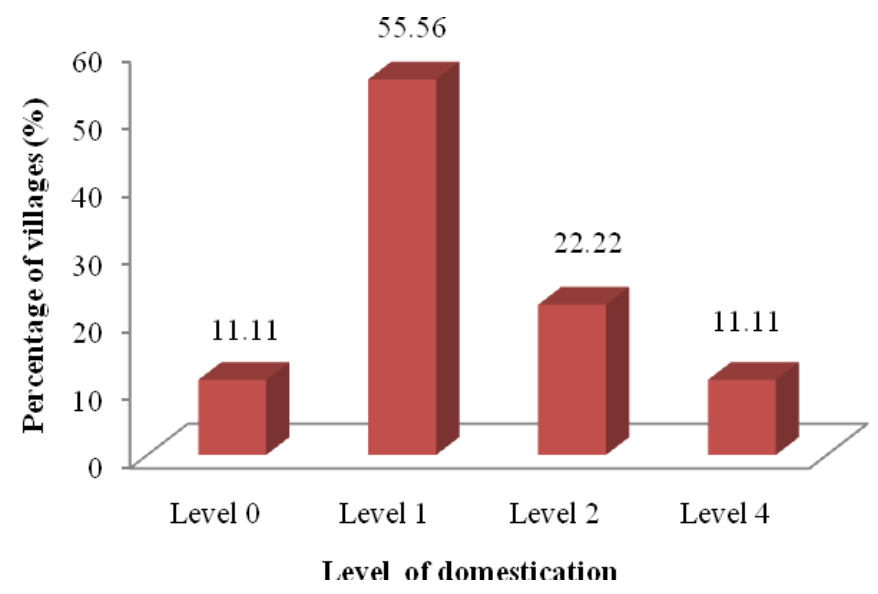

Fig. 2: Levels of domestication of Lippia multiflora. 
Lippia multiflora is capable of sexual reproduction and also of vegetative propagation through stem cuttings. Seeds collected from mature plants are kept in various containers among with Polythene bag $(58.66 \%$ of responses), piece of cloth (24.72\% of responses) and bottle (16.62\% of responses) and this can last 4 to 5 months. From the farmers domesticating the species interviewed, $75.28 \%$ use botanical seeds and $24.72 \%$ use cuttings. Seeds are grown through nursery.

\section{Utilization and medicinal values}

A great majority $(76.92 \%)$ of the interviewees consume Lippia multiflora as vegetable. The parts of the plant mostly used are the leaves (60\% of responses) and the flowers (25\% of responses) (Fig. 3). Leave and flower of this vegetable can be collected at the time of abundance, shade dried, crushed into powder and stored in bags, plastic containers or gourds for regular use during the long dry seasons. These results are similar to those reported by Adjatin et al. (2012) on Crassocephalum rubens and by Fah et al. (2013) on Catharanthus roseus Linn and Phyllanthus amarus Schumach. \& Thonn.

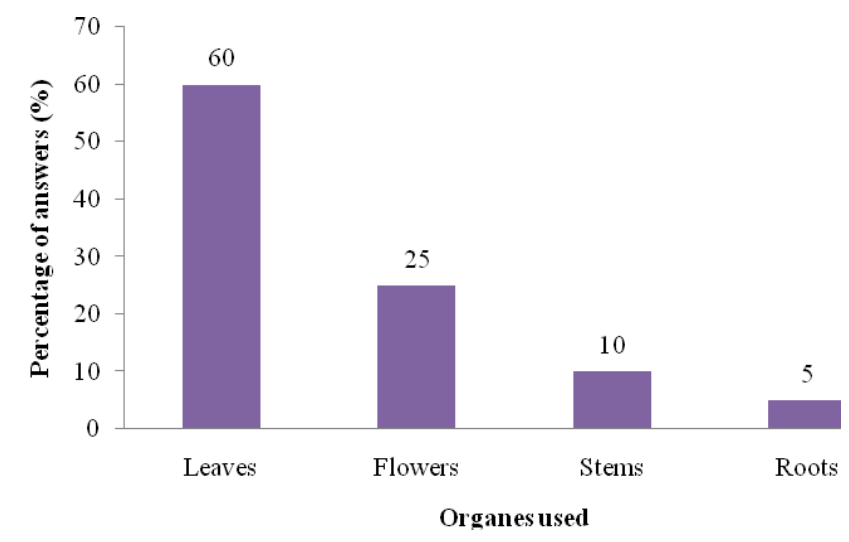

Fig. 3: Parts of the plant used and their relative importance.

The frequencies of consumption of the species varied across ethnic groups (Fig. 4). Ethnic groups Mahi, Ifè, Idasha and Tchabè consume more frequently than the group Fon. Such variation of consumption frequency was also reported on Alternanthera sessilis, Bidens pilosa and Launaea taraxacifolia (Sanoussi et al., 2015). Local communities surveyed perceived Lippia multiflora as of high nutritional values. The powder is generally marketed traditionally either in the market or along the roads. It is important to conduct microbial analysis in order to determine the conservation' length of the powder. Also for sanitary reasons and to accelerate the drying process in order to help the communities in increasing this vegetables' quantity they usually conserve, it is necessary to improve the methods of drying using solar driers as proposed by Dansi et al. (2009).

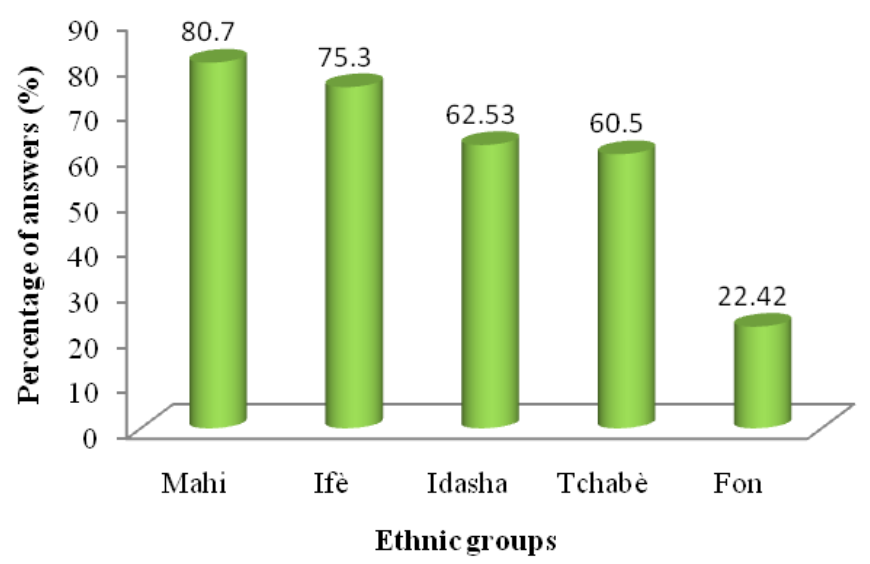

Fig. 4: Frequency of consumption of Lippia Multiflora across ethnic areas.

All the interviewees reported that Lippia multiflora has a lot of medicinal values and its different parts even have specific medicinal properties (Table 2). The leaves for instance are used to treat malaria, fever, dysentery, blood pressure, diarrhea, anemia, headaches, constipation, fatigue, ulcer and hemorrhoid. In total 19 illnesses are treated by the different organs of Lippia multiflora (Table 2). The frequencies of citation of the illnesses treated by Lippia multiflora are shown in Fig. 5. The most cited was malaria. The leaves are the mostly used in the treatment of the illnesses as it was reported to have $79 \%$ of the medicinal virtues known for the plant. Similar results were reported by Yemoa et al. (2008) on Vernonia amygdalina, Ocimum gratissimum and Moringa oleifera and also by Herzog (1995); Pascual et al. (2001); Kanco et al. (2004) and Oussou et al. (2008).

Table 2. Illnesses treated by the different parts of Lippia multiflora.

\begin{tabular}{lllll}
\hline \multirow{2}{*}{ Illnesses } & \multicolumn{4}{l}{ Parts of plant } \\
\cline { 2 - 5 } & Leaves & Flowers & Stems & Roots \\
\hline Malaria & + & - & - & - \\
Vermifuge & + & + & - & - \\
Fever & + & - & + & - \\
Dysentery & + & - & - & - \\
Laxative & + & + & + & - \\
Antibiotic & + & - & - & - \\
Headaches & + & - & - & - \\
Diarrhea & + & + & - & - \\
Constipation & + & + & - & - \\
\hline
\end{tabular}




\begin{tabular}{|c|c|c|c|c|}
\hline \multirow{2}{*}{ Illnesses } & \multicolumn{4}{|c|}{ Parts of plant } \\
\hline & Leaves & Flowers & Stems & Roots \\
\hline Tiredness & + & + & - & - \\
\hline Anemia & + & - & - & - \\
\hline Diuretic & + & + & + & - \\
\hline $\begin{array}{l}\text { Blood } \\
\text { pressure }\end{array}$ & + & - & - & - \\
\hline Haemorrhoid & + & + & - & + \\
\hline $\begin{array}{l}\text { Pains of } \\
\text { teeth }\end{array}$ & - & - & - & + \\
\hline Ulcer & + & + & - & + \\
\hline Chickenpox & - & - & + & - \\
\hline Aphrodisiac & - & - & - & + \\
\hline Epilepsy & - & - & - & + \\
\hline
\end{tabular}

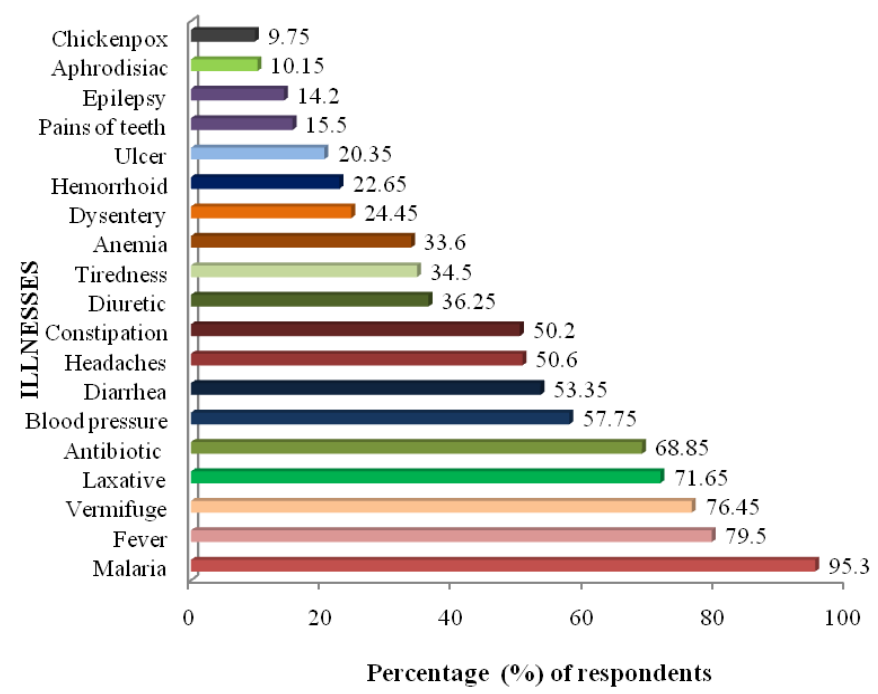

Fig. 5: Importance of citations of the illnesses treated by Lippia multiflora.

\section{Conclusion}

Lippia multiflora is a good nutraceutical and aromatic leafy vegetable that should be promoted. Its domestication is in progress in Benin and should be supported with agronomic trials. For the valorization of the species (Lippia multiflora), the following research activities are necessary:

- Phytochemical screening of leaves and flowers of different ecotypes.

- Assessment of the nutritional properties of the leaves and of the flowers.

- Comparative assessment of the availability in tea from fresh or dry leaves of the nutritional (vitamins, macro and microelements) and phytochemical components of the plant.

- Evaluation in collaboration with specialized physicians of the real capacity of the plant in treating the illnesses indicated.

\section{Conflict of interest statement}

Authors declare that they have no conflict of interest.

\section{Acknowledgement}

This study was carried out in the laboratory of Biotechnology, Genetic Resources and Animal and Plant Breeding (BIORAVE) of the Faculty of Science and Technology of Dassa (Benin). We gratefully acknowledge the valuable assistance of the person we met during the survey.

\section{References}

Adjanohoun, E., de Souza, S., 2002. Guide Pratique de Phytothérapie (La Santé par les Plantes-100 Plantes Médicinales du Bénin).

Adjatin, A., Dansi, A., Eze, C.S., Assogba, P., DossouAminon, I., Akpagana, K., Akoègninou, A., Sanni, A., 2012. Ethnobotanical investigation and diversity of Gbolo [Crassocephalum rubens (Juss. ex Jacq.) S. Moore and C. crepidioides (Benth.) S. Moore], a traditional leafy vegetable under domestication in Benin. Genet. Resour. Crop Evol. 59(8), 1867-1881.

Adomou, A.C., 2005. Vegetation Patterns and Environmental Gradients in Benin: Implications for Biogeography and Conservation. Ph.D. thesis, Wageningen University the Netherlands. 136p.

Agre, A.P., Kouchade, S., Odjo, T., Dansi, M., Nzobadila, B., Assogba, P., Dansi, A., Akoegninou, A., Sanni, A., 2015. Diversité et évaluation participative des cultivars du manioc (Manihot esculenta Crantz) au Centre Bénin. Int. J. Biol. Chem. Sci. 9(1), 388-408.

Akoègninou, A., van der Burg, W.J., van der Maesen, L.J.G., 2006. Flore Analytique de Bénin, Backhuys Publishers, Leiden. 1034p.

Avlessi, F., Alitonou, G., Sohounhloue, D.K., Menut, C., Bessière, J.M., 2005. Chemical and biological investigation of Lippia multiflora Mold. essential oil from Benin. Aromatic Plants of Tropical West Africa. Part XIV. J. Essent. Oil Res. 17, 405-407.

Bouquet, A., Debray, M., 1974. Plantes Médicinales de Côte d'Ivoire. ORSTOM, Paris Inc.

Casas, A., Otero-Arnaiz, A., Perez-Negron, E., ValienteBanuet, A., 2007. In situ management and 
domestication of plants in Mesoamerica. Ann. Bot. 100, 1101-1115.

Dansi, A., Adjatin, A., Adoukonou-Sagbadja, H., Faladé, V., Adomou, A.C., Yedomonhan, H., Akpagana, K., de Foucault, B., 2009. Traditional leafy vegetables in Benin: Folk nomenclature, species under threat and domestication. Acta Bot. Gallica. 156, 183-199.

Dansi, A., Adjatin, A., Adoukonou-Sagbadja, H., Faladé, V., Yedomonhan, H., Odou, D., Dossou, B., 2008. Traditional leafy vegetables and their use in the Benin Republic. Genet. Resour. Crop Evol. 55, 1239-1256.

Dansi, A., Vodouhè, R., Azokpota, P., Yedomonhan, H., Assogba, P., Adjatin, A., Loko, Y.L., DossouAminon, I., Akpagana, K., 2012. Diversity of the neglected and underutilized crop species of importance in Benin. Scient. World J. 2012, Article ID 932947, 19p.

Dossou-Aminon, I., Loko, L.Y., Adjatin, A., Dansi, A., Elangovan, M., Chaudhary, P., Vodouhè, R., Sanni, A., 2014. Diversity, genetic erosion and farmer s preference of sorghum varieties [Sorghum bicolor (L.) Moench] in North-Eastern Benin. Int. J. Curr. Microbiol. Appl. Sci. 3(10), 531-552.

Ekissi, A.C., Konan, A.G., Yao-Kouame, A., Bonfoh, B., Kati-Coulibaly, S., 2014. Sensory evaluation of green tea from Lippia multiflora Moldenke leaves. Eur. Scient. J. 10(3), 536-545.

Ekissi, A.C., Yao-Kouame, A., Konan, A.G., Alui, K.A., Agbo, N.G., Kati-Coulibaly, S., 2013. Manufacturing process and various uses of Savannah herbal tea (Lippia multiflora) in Côte d'Ivoire. Asian J. Agric. Rural Develop. 3(8), 597-608.

Fah, L., Klotoé, J.R., Dougnon, V., Koudokpon, H., Fanou, V.B., Dandjesso, C., Loko, F., 2013. Ethnobotanic study of plants used in the treatment of diabetes in pregnant women in Cotonou and Abomey-Calavi (Benin). J. Anim. Plant Sci. 18(1), 2647-2658.

Hammer, K., 1984. The domestication syndrome. Genet. Resour. Crop Evol. 32, 11-34.

Harlan, J.R., 1992. Crops and Man. $2^{\text {nd }}$ Edn. American Society of Agronomy/ Crop Science Society of America, Madison (WI).

Herzog, F., 1995. Les plantes de cueillettes utilisées dans l'alimentation en Côte d'Ivoire centrale. Valeur nutritive et importance alimentaire des vins de palme. In : L'Afrique part tous les matins. Stratégies pour dépasser le bricolage quotidien (Eds. : Sotta B., Vischer L. R.). Peter Lang, Bern (Swizerland). pp.203-213.

Hildebrand, E.A., 2003. Motives and opportunities for domestication: an ethno-archaeological study in southwest Ethiopia. J. Anthropol. Archaeol. 22, 358375.

Kanco, C., Koukoua, G., N'Guessan, Y.T., Fournier, J., Pradère, J.P., Toupet, L., 2004. Contribution à l'étude phytochimique de Lippia multiflora (Verbenaceae). C. R. Chemie. 7, 1029-1032.

Mangambu, M., Mushagalusa, K.F., Kadima, N.J., 2014. Contribution á l'étude phytochimique de quelques plantes médicinales antidiabétiques de Bukavu, R.D Congo. J. Appl. Biosci. 75, 6211-6220.

Mindiédiba, J.B., Almaraz, A.N., Nâg-Tiero, M.R., Mouhibatou, Y.Z., Jeanne, M.R., Germaine, N.O., 2013. Lippia chevalieri Moldenke A brief review of traditional uses, phytochemistry and pharmacology. Int. J. Drug Deliv. 4(3), 289-296.

Oussou, K.R., Yolou, S., Boti, J.B., Guessennd, K.N., Kanko, C., Ahibo, C., Casanova, J., 2008. Etude chimique et activité antidiarrheique des huiles essentielles de deux plantes aromatiques de la pharmacopée ivoirienne. Eur. J. Scient. Res. 24(1), 94-103.

Parker, M.I., Lopez, I., Petersen, J.J., Anaya, N., Cubilla-Rios, L., Potter, D., 2010. Domestication syndrome in Caimito (Chrysophyllum cainito L.) fruit and seed characteristics. Econ. Bot. 64, 161175.

Pascual, M.E., Slowing, K., Carretero, E., Sánchez, M.D., Villar, A., 2001. Lippia: Traditional uses, chemistry and pharmacology. J. Ethnopharmacol. 76, 201-214.

Pourkheirandish, M., Komatsuda, T., 2007. The importance of barley genetics and domestication in a global perspective. Ann. Bot. 100, 999-1008.

Sakuma, S., Salomon, B., Komatsuda, T., 2011. The domestication syndrome genes responsible for the major changes in plant form in the Triticeae crops. Plant Cell Physiol. 52, 738-749.

Sanoussi, F., Ahissou, H., Dansi, M., Hounkonnou, B., Agre, P., Dansi, A., 2015. Ethnobotanical investigation of three traditional leafy vegetables [Alternanthera sessilis (L.) DC., Bidens pilosa L., Launaea taraxacifolia Willd.] widely consumed in southern and central Benin. J. Biodiv. Environ. Sci. 6(2), 187-198.

Vodouhè, R., Dansi, A., 2012. The "Bringing into Cultivation" phase of the plant domestication process and its contributions to in situ conservation of genetic resources in Benin. Scient. World J. 2012, 
Article ID 176939. 13p.

Vodouhè, R., Dansi, A., Avohou, H.T., Kpèki, B., Azihou, F., 2011. Plant domestication and its contributions to in situ conservation of genetic resources in Benin. Int. J. Biodiv. Conserv. 3, 4056.
Yemoa, A.L., Gbenou, J.D., Johnson, R.C., Djego, J.G., Zinsou, C., Moudachirou, M., Quetin-Leclercq, J., Bigot, A., Portaels, F., 2008. Identification et étude phytochimique de plantes utilisées dans le traitement traditionnel de l'ulcère de Buruli au Bénin. Ethnopharmacol. 42, 1-8.

\section{How to cite this article:}

Djengue, H. W., Dansi, A., Adjatin, A., Dossou-Aminon, I., Dansi, M., Sanni, A., 2017. Ethnobotanical investigation of Lippia multiflora Moldenke, a local aromatic leafy vegetable under domestication in Benin. Int. J. Curr. Res. Biosci. Plant Biol. 4(5), 44-51. doi: https://doi.org/10.20546/ijcrbp.2017.405.005 